\section{Antologia da Crítica Cinematográfica em Vidas Secas}

\author{
Atílio AVANCINI ${ }^{1}$ \\ Juliana PENNA ${ }^{2}$
}

Resumo: Este estudo versa sobre a crítica cinematográfica produzida em torno do filme Vidas Secas (1963) do diretor Nelson Pereira dos Santos. O objetivo da pesquisa é promover uma antologia da cobertura jornalística da grande imprensa durante o lançamento e a repercussão do filme. A concepção da adaptação audiovisual faz manter a estrutura narrativa do romance homônimo de Graciliano Ramos como retaguarda para discutir problemas sociais evitando, inclusive, sofrer a censura do governo militar. Vidas Secas reflete um projeto capaz de compreender o Brasil. A pesquisa apresenta críticas (jornalísticas e literárias) que enfoca a relação mídia e cinema. Apesar do aumento da produção audiovisual, Vidas Secas é raro estímulo na construção da identidade brasileira e como forma de contestação em relação à política social.

Palavras-chave: comunicação; audiovisual; crítica cinematográfica; cinema novo; arte brasileira

\section{Antología de la Crítica Cinematográfica en Vidas Secas}

Resumen: Este estudio trata sobre la crítica cinematográfica producida en relación a la película Vidas Secas (1963) del director Nelson Pereira dos Santos. El objetivo de la investigación es promover una antología de la cobertura periodística de la grande imprenta durante el lanzamiento y la repercusión de la película. La concepción de la adaptación audiovisual mantiene la estructura narrativa de la novela homónima de Graciliano Ramos como retaguardia para discutir problemas sociales evitando, inclusive, sufrir la censura del gobierno militar. Vidas Secas reflexiona sobre un proyecto capaz de comprender a Brasil. La investigación presenta críticas (periodísticas y

1 Atílio Avancini é professor doutor (nível 2) da Escola de Comunicações e Artes da Universidade de São Paulo com pós-doutorado na Université Sorbonne Nouvelle Paris 3 (avancini@usp.br).

2 Juliana Penna é pesquisadora e jornalista graduada pela Escola de Comunicações e Artes da Universidade de São Paulo (julianapenna@ gmail.com). literarias) que enfoca la relación de los medios y el cine. A pesar del aumento de la producción audiovisual, Vidas Secas es un raro estímulo en la construcción de la identidad brasileña y como forma contestataria en relación a la política social.

Palabras clave: comunicación; audiovisual; crítica cinematográfica; cine nuevo; arte brasileño

\section{Introdução}

O cineasta Nelson Pereira dos Santos (1928) troca cartas com o escritor Graciliano Ramos (18921953), com quem discute a possibilidade de realizar uma adaptação do livro Vidas Secas para o cinema. No entanto, mesmo com o aval do escritor, o drama literário - publicado em 1938 sobre uma família de retirantes que foge da seca nordestina - iria ganhar som e movimento vinte e cinco anos depois no mesmo Estado de Alagoas onde havia sido inspirado.

O longa-metragem, Vidas Secas, lançado em 1963, faz sucesso numa época em que o cinema no Brasil é pouco diversificado. Falta espaço para experimentações e o cinema de autor praticamente inexiste. Os motivos abrangem desde o poder que o monopólio do cinema norte-americano exerce sobre distribuidoras e exibidoras até o constrangimento de uma parte da população em relação à qualidade do produto audiovisual brasileiro.

Quando Vidas Secas é lançado, com direção e roteiro de Nelson Pereira dos Santos, o cinema brasileiro não só tem espaço muito reduzido, como há quem com muita relutância o considere cinema. Seu sucesso se dá de forma inusitada e peculiar, em grande parte pela expectativa criada em torno de sua pré-produção inspirada na obra clássica da literatura brasileira. Entretanto, parte do grande público do filme estranha a sua narrativa. $\mathrm{O}$ movimento da câmera, o tempo lento, a economia de diálogos, o alto contraste da luz e a tensão musical resultam numa experiência visual e sonora muito diferente da então observada.

O fato é que a história de Fabiano, Sinhá Vitória, Baleia e os dois meninos transfere sua notoriedade - e dimensão trágica - também para o cinema. Graciliano Ramos demarca assim seu cenário dramático: "Miudinhos, perdidos no deserto queimado, os fugitivos agarraram-se, somaram as suas desgraças e os seus pavores. O coração de Fabiano bateu junto do coração de sinhá Vitória, um abraço cansado aproximou os farrapos que os cobriam" (RAMOS, 2012, p. 14). Embora a narrativa literária retrate a pobreza da família sertaneja, a ênfase 
do escritor é a capacidade de articular o sonho do futuro para a alfabetização dos meninos na cidade grande.

O movimento Cinema Novo, surgido no começo dos anos 1960 e idealizado pelo baixo orçamento, alinha valores e estilos da vanguarda europeia para discutir a situação social brasileira. A tentativa é despertar a consciência do público com filmes realistas sobre a miséria e a luta de classes. Esta antologia, portanto, procura entender a forma como Vidas Secas exercita o jornalismo cultural através de trabalhos jornalísticos. O objetivo desta análise é reunir uma coleção da cobertura jornalística da grande imprensa e de escritos literários, como formadora da opinião pública, que enfoca a relação mídia e cinema durante o lançamento e a repercussão do filme. A seleção de críticas é editada pelos autores.

\section{Antes da estreia}

Ao assumir uma adaptação fiel do romance, o projeto cinematográfico passa a receber as luzes dos holofotes da crítica durante todas as fases de produção. E com o apoio literário nossa cultura é valorizada, evitando-se o ataque da censura militar. O filme Vidas Secas é pauta muitos meses antes de estrear nas primeiras salas do Rio de Janeiro. A importância da obra de Graciliano Ramos e a reputação do diretor (eleito bem mais tarde para a Academia Brasileira de Letras) se somam para que a cobertura jornalística se torne das mais extensas até então já dedicadas ao cinema brasileiro.

A notícia da transposição cinematográfica de um livro relevante tem valor jornalístico em si. E a cobertura não se limita a satisfazer a curiosidade do público sobre o que está se passando durante as fases de produção do projeto, mas também de manifestar as expectativas dos leitores da obra literária em relação ao produto final da adaptação proposta. Algumas décadas antes do advento da internet, a divulgação da produção de Vidas Secas demonstra manifestação precoce dessa tendência que hoje opera massivamente no noticiário cultural.

O filme tem sua primeira exibição aberta ao público no Rio de Janeiro, em 22 de agosto de 1963, sendo pré-anunciado e divulgado desde fevereiro do mesmo ano. O jornal Folha de S. Paulo (17/08/1963) registra uma foto do set de filmagem de Nelson Pereira dos Santos e é publicada entrevista com o diretor de fotografia Luiz Carlos Barreto. A recepção positiva e quase unânime da crítica e da intelectualidade consolida Vidas Secas como sucesso em termos estéticos, mas, principalmente, porque a adaptação foi considerada fiel ao espírito da obra literária. $\mathrm{Na}$ opinião jornalística, a adaptação é reconhe- cida como a que melhor realizara a transposição de uma obra literária às telas.

\section{O olhar da imprensa}

Vidas Secas tem, graças a seu sucesso, boa parte de sua documentação jornalística arquivada e preservada no acervo da Cinemateca de São Paulo. Do que existe e é acessível à pesquisa, nota-se que, por mais peculiar que a exibição de Vidas Secas tenha se configurado, sua repercussão reflete um objeto artístico capaz de fazer o público pensar e compreender o país. $\mathrm{Na}$ linha temática do Cinema Novo se privilegia discutir a população rural, a pobreza e a cultura popular. Vidas Secas, portanto, se torna espaço para denúncias de fácil compreensão - pelas imagens - e sem pretensões comerciais.

A crítica jornalística recorre com frequência a padrões europeus de avaliação. Em artigo no Diário de Notícias, "Um Filme para Kennedy Ver", Silveira Sampaio caracteriza o filme como "internacional, sendo profundamente regional". Ele o compara aos westerns norte-americanos. E afirma que Nelson Pereira dos Santos retrata a realidade sem concessões. "Ou muito me engano, Vidas Secas terá um êxito internacional maior que o nacional" (SAMPAIO, 1963).

A questão da temática também é abordada nas coberturas jornalísticas do lançamento de Vidas Secas. Enquanto uns se aborrecem pelo pouco espaço concedido à vida urbana, outros enxergam nessa tendência uma possível saída. "A temática nordestina foi durante muito tempo a preferida pela melhor literatura brasileira moderna e a tendência de nosso cinema é retomar esse curso" (SALLES GOMES, 1963, p. 70). Entretanto, a visão urbana se faz presente com protagonistas bem diferenciados do tipo sertanejo: um homem alto barbado para Fabiano e uma mulher negra para Sinha Vitória.

A estreia no Rio de Janeiro não é muito popular, publica-se no Correio da Manbã, "Vidas Secas", reação de estranhamento por parte de uma espectadora à exibição. "À saída, pudemos surpreender em retalhos de diálogo a censura de uma jovem esposa ao marido que a tinha levado para ver aquilo 'Este filme é o fim"' (CORREIO DA MANHÃ, 1963). Entretanto, o jornalista e crítico de cinema Ely Azeredo rechaça a sala carioca que lança o filme e o retira após uma semana em cartaz para cumprir o decreto de obrigatoriedade. Azeredo afirma que a permanência é curta para evitar um eventual confronto com a indústria cinematográfica norte-americana Metro Goldwyn Mayer (SALLES GOMES, 1963, p. 70). 
Rodado no set de filmagem em Palmeira dos Índios (Estado de Alagoas), o audiovisual é exibido publicamente pela primeira vez em março de 1964, em São Paulo, no mesmo mês da instauração do golpe civil-militar. Após quase sete meses, desde que o filme de Nelson Pereira dos Santos é lançado nos cinemas cariocas, publica-se artigo em O Estado de S. Paulo, "Vidas Secas é a Grande Atração": "suscitou as mais ardentes loas não só da crítica como também de intelectuais, artistas, políticos e personalidades (...) numa impressionante manifestação de unanimidade e numa prova de interesse com as quais nosso sempre desprotegido e depreciado cinema jamais teria sonhado em contar antes" (O ESTADO DE S. PAULO, 1964).

Vidas Secas quase não viaja a Cannes para participar da competição mais reconhecida do mundo cinematográfico. Finalizado em 1963 e com a mesma temática nordestina, Deus e o Diabo na Terra do Sol de Glauber Rocha é selecionado pelo Itamarati para representar o Brasil no festival. A imprensa, em geral, se resigna à decisão da comissão selecionadora, formada pelos críticos Otávio Bomfim, José Sanz, Humberto Mauro, Tati de Morais e Almir de Castro, além dos diplomatas e chefes do setor de Cinemas e da Divisão Cultural do Itamaraty, Jorge Oliveira Maia, Arnaldo Castilho e Mário Dias Costa.

Sobre a preterição do filme de Glauber para ser apresentado em Cannes, a imprensa opta por enfatizar a dificuldade na tomada de decisão, que acaba por acatar como justa. Em entrevista para O Jornal do Rio de Janeiro, "Itamarati Selecionou Filme para o Festival de Cannes", o membro da comissão, Jorge Oliveira Maia, pondera "Vidas Secas, em particular, disputou até as últimas horas da seleção com Deus e o Diabo na Terra do Sol, tendo sido finalmente escolhido o último (...) se houvesse possibilidade de se mandar mais de um filme para Cannes, iriam os dois" (MAIA, 1964).

Entretanto, é publicado no jornal $O$ Estado de $S$. Paulo, "Fitas para o Festival de Cannes" (01/04/1964), que anuncia seis novos filmes selecionados pela direção de Cannes para competir na França. Ou seja, o convite do festival assegura a ida da obra de Nelson Pereira dos Santos como concorrente e repercute na imprensa em matérias de crescente otimismo. Agora o Brasil levaria não só um, mas dois concorrentes para o festival internacional de cinema. E obras cinematográficas de dois autores de peso.

\section{Premiação no Festival de Cannes}

A direção governamental trabalhista do presidente João Goulart (1962-1964) propõe um sistema de reforma agrária, anunciando a desapropriação de terras para evitar, dentre outros, o continuísmo da oposição entre o coronel (patrão latifundiário) e o jagunço (sertanejo miserável) - a distância entre um e outro deveria ser encurtada. E Goulart provoca as elites políticas com a nacionalização de empresas estrangeiras de serviços públicos.

Com o governo militar, que se estende durante 21 anos, de 01 de abril de 1964 a 15 de março de 1985, destitui-se Goulart e busca-se um novo viés à política brasileira, o movimento é apoiado pelo Congresso Nacional e pelos Estados Unidos da América. Entretanto, 1964 é um dos anos em que o Brasil vai otimista a Cannes. $E$ isso se reflete quase em uníssono nas publicações da imprensa. Vale destacar que os militares valorizam a cultura nacional durante a primeira etapa do modelo político, que ocorre entre 1964 e 1968.

Se a primeira escolha privilegia um filme mais polêmico do que Vidas Secas, este não é considerado um concorrente menor. "O Brasil está fantasticamente representado em Cannes", conforme é publicado no Jornal do Comércio do Rio de Janeiro, "Cannes 64". E como se vê mais adiante no mesmo artigo: "O Brasil vai bem no cinema apesar dos mandos e desmandos das distribuidoras estrangeiras" (JORNAL DO COMÉRCIO, 1964).

Após o conhecimento de que Vidas Secas reforça a concorrência brasileira no Festival de Cannes, uma vitória parece estar próxima, segundo as novidades culturais da imprensa escrita. A Folha de S. Paulo informa em "Vidas Secas, $1^{a}$ da América em Cannes" sobre a exibição oficial dos filmes de Nelson e Glauber no festival: "Vidas Secas e Deus e o Diabo na Terra do Sol foram muito elogiados pela crítica e são considerados sérios concorrentes à Palma de Ouro" (FOLHA DE S. PAULO, 1964). Já em O Estado de S. Paulo, "Artes na Semana": "A fita brasileira de Nelson Pereira dos Santos recebeu a boa acolhida dos mais influentes críticos franceses e uma moção de aplauso dada à direção do festival por ter tido a iniciativa de convidá-la especialmente" (O ESTADO DE S. PAULO, 1964).

A opinião do crítico Tom Rowe, publicada no Correio do Povo, "Vidas Secas: sucesso no Festival de Cannes", sugere que falta à obra de Nelson "alguma coisa indefinível para ser um grande filme" (ROWE, 1964). Vale destacar que a imprensa também não concede destaque à cobertura das performances dos filmes rivais - a única preocupação é o Brasil. E o público fica sem o contraponto aos trabalhos de Glauber Rocha e Nelson Pereira dos Santos. O crítico Claudio Mello e Souza, Jornal do Brasil, aproveita para promover comparações.

83

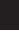


O argumento de que o Brasil já estaria derrotado em Cannes por antecipação por causa do prêmio dado recentemente a O Pagador de Promessas parece-me caducado se é que existiu e preponderou. Pode-se mesmo dizer, com certo exagero, que houve justiça em dar-se ao Brasil, através de $O$ Pagador de Promessas, não um prêmio, mas um estímulo (MELLO E SOUZA, 1964).

Percebe-se na imprensa o uso recorrente da questão comparativa. Como o artigo "Cinema brasileiro chuta a gol", que assim avalia O Pagador de Promessas. "O filme de Anselmo Duarte-Dias Gomes é demasiado acessível ao grande público para que os 'intelectualizados' do cinema possam admirá-lo sem medo de estar incorrendo em "vulgaridade" (TRIBUNA DA IMPRENSA, 1963). Se em 1962 o Brasil conquista o prêmio com um bom filme, deveria ser merecedor do mesmo em 1964, quando o país é representado não só por um, mas por dois filmes de melhor qualidade. Mas Mello e Souza, Jornal do Brasil, deprecia o prêmio ganho dois anos antes. "Não poderemos ganhar se houver filmes melhores. Mas também não queremos mais ganhar se houver filmes melhores. Já nos fizeram esse tenebroso favor" (MELLO E SOUZA, 1964).

A decisão de Cannes é de que a Palma de Ouro de 1964 vai para as mãos do diretor francês Jacques Demy em Les Parapluies de Cherbourg. De fato, quando a consagração não chega a Vidas Secas e a Deus e o Diabo na Terra do Sol com o prêmio principal, a reação não é de estarrecimento. Mas um misto de conformismo e indignação com o julgamento, como esta fala do jornalista Novaes Teixeira em O Estado de S. Paulo, "França Vence em Cannes: 3 prêmios para fita brasileira". "Pode o Brasil estar satisfeito com a presença do seu novo cinema no festival cinematográfico de Cannes. Foi digna, séria, autêntica e promissora. E podem ter certeza de que o Brasil este ano em Cannes recolheu menos louros do que merecia" (TEIXEIRA, 1964).

Nelson Pereira dos Santos, no entanto, não volta ao Brasil de mãos vazias. Vidas Secas bate o recorde de prêmios do júri não-oficial. Ao todo são três: a láurea do Instituto Católico da Indústria Cinematográfica, o de arte e ensaio e o de juventude. Sobre este último, Nelson Pereira diz a Novaes Teixeira de O Estado de S. Paulo em "Palavras do Diretor": "agrada-me especialmente, pois tenho três filhos em casa que ficarão contentes com o pai" (TEIXEIRA, 1964).

\section{Roteiro e adaptação}

Vidas Secas situa-se de forma peculiar não só nas telas de cinema, mas também na resposta da imprensa. Se a abordagem é sempre simpática à estética, à atitude do filme e ao trabalho de seu diretor e fotógrafo, o reconhecimento adquire focos e direcionamentos diferentes em cada comentário. No entanto, num momento político tenso e envolto pelo gesto ditatorial, sua chave é protestar silenciosamente e promover a reflexão pela arte e literatura. Por isso, no texto de abertura do filme, Nelson Pereira dos Santos reforça a ideia da importância e do respaldo do livro homônimo de Graciliano Ramos.

Este filme não é apenas a transposição fiel, para o cinema, de uma obra imortal da literatura brasileira. É antes de tudo, um depoimento sobre uma dramática realidade social de nossos dias e extrema miséria que escraviza 27 milhões de nordestinos e que nenhum brasileiro digno pode mais ignorar (VIDAS SECAS, 1963).

Paulo Emílio Salles Gomes valoriza a experiência de ensinamentos para estudiosos de estética. "O leitor-expectador de Vidas Secas adquire o sentimento privilegiado de conhecer uma obra através de duas artes" (SALLES GOMES, 1963, p. 70). Para muitos da crítica, preocupados em relação à adaptação audiovisual, a obra cinematográfica envolve mudanças na narração e linguagem, mas corresponde às expectativas pela mesma estrutura com o original. "À sua maneira, Nelson é mais fiel a Graciliano do que o próprio escritor” (AZEREDO, 2009, p. 322).

Presente em quase todas as críticas, a fidelidade é na verdade para a imprensa um lugar-comum, ramificando-se em uma intensa variedade de definições e exemplificações. Esta característica é marcante no modo como o diretor transporta os personagens para as telas - especificamente Fabiano -, tornando-os ainda mais submissos do que no romance. A autoria do cineasta se faz perceber nos episódios pontilhados ao longo dos 103 minutos de duração do filme, que não encontram precisamente correspondentes em meio aos eventos do romance escrito, mas lidam bem com a essência da obra.

Está entre esses trechos a comentada cena que evidencia a possibilidade, ao angustiado Fabiano, de se tornar cangaceiro (justiceiro ou bandido-social), "da qual não existe pelo menos traço algum na narrativa original”. 
De fato, identifica-se "correspondência exata e harmoniosa entre essa passagem e as veleidades do personagem literário, sertanejo Fabiano, que nutre fantasias de ingresso no cangaço como forma de rebelião contra as forças sociais que o oprimem" (SALLES GOMES, 1963, p. 70).

Ao ambientar tal passagem ao roteiro do filme, Nelson Pereira dos Santos não deixa de dialogar com o original. $\mathrm{O}$ argumento de Ely Azeredo se faz presente na construção do personagem Fabiano, senão mais passivo, igualmente destituído de iniciativa e à mercê das condições extenuantes da vida árida. A imagem da família desamparada pelo caminho agreste assume o contraponto ao meio criminoso - e à cadeia -, ganhando conteúdo e caráter expressivo que não lhe é conferido na obra literária. Há também coerência com o romance ao interpretar a visão dos sertanejos, que vivem bravamente uma trajetória pontilhada de episódios significativos, "erigindo-se inesperadamente em heróis” (CANDIDO, 2012, p. 66).

Outro momento da obra em que o diretor escapa do original é "na sequencia em que o filho mais velho pergunta à mãe o que é inferno e acaba sendo castigado, o que o leva a meditar sobre o assunto" (SALLES GOMES, 1963, p. 70). Esta cena tem uma readaptação - não há a reflexão do personagem após a punição. Todavia, como o crítico observa, sem considerá-la uma perda: "traiu frontalmente o escritor numa passagem bem definida, mas de maneira a permanecer estritamente fiel ao espírito global do livro" (SALLES GOMES, 1963, p. 70). Se por um lado esta cena diminui o interesse do menino em compreender a palavra inferno, por outro lado cria-se uma metáfora imagética com a luz estourada do semiárido como espaço amaldiçoado.

Há outro episódio sem equivalente no romance, citado em O Estado de S. Paulo por David E. Neves, "A Verdade do Nordeste", que retrata Fabiano a contemplar uma aula de violino na residência do dono da fazenda: "É este um dos momentos culminantes da fita e se deve à estética do singelo" (NEVES, 1963). No filme, o silêncio e o pensamento não verbalizado de Graciliano também prevalece, não só pela escassez de diálogos do roteiro, mas por uma série de recursos plásticos inspirados pela interpretação do diretor. Como, por exemplo, o chiado do carro de boi que é sonoplastia emitida pelas cordas suplicantes do violino, que evoca o peso da opressão. $\mathrm{Ou}$ seja, esses elementos afastam a obra de uma "tradução servil do texto literário à linguagem cinematográfica" (AZEREDO, 2009, p. 322).

Ao invés de trazer sob a forma de diálogo, ou mesmo de monólogo, a linha de pensamento de Fabiano, que no romance perdura por páginas, é evidenciada pelo respeito e compreensão do personagem. Há uma sequência maior de episódios com interpretações mais plásticas das emoções. Isto é, o lado subjetivo do sertanejo permanece implícito, recôndito e inaudível, que não encontra vias de expressão - desejo de Graciliano Ramos. Assim sendo, a história de Fabiano, Sinhá Vitória, Baleia e os dois meninos passa a ocupar o papel emblemático tanto no audiovisual como na literatura: "o mais alto grau de abstração atingido entre nós pelo cinema" (BERNADET, 2007, p. 82). E, este sim, é o maior feito do filme em questão.

Se o roteiro escrito por Nelson Pereira dos Santos é bem-sucedido na adaptação literária, os recursos plásticos (Luiz Carlos Barreto e José Rosa), musicais (Leonardo Alencar) e cênicos (Átila Iório, Maria Ribeiro, Gilvan Lima, Genivaldo Lima, Joffre Soares e Orlando Macedo) também são coerentemente utilizados. $\mathrm{O}$ conceito cinemanovista mescla a expressão artística do diretor à técnica de produção, questionando a difícil realidade nacional. Mesmo explorando gêneros e assuntos diversos o foco é o cinema brasileiro mais politizado.

O diretor intercala o estilo de produção com alguns recursos moldados pelo diálogo entre as linguagens verbal e não-verbal. Por exemplo, o modo direto como a câmera na mão é empregada e o uso da luz saturada, sem filtros, tornam-se análogos à forma seca e lacônica utilizada pelo escritor. "Você tem uma estética que define uma irregularidade, que chama atenção para a câmera, não é como uma câmera industrial, que desliza, que você esquece que ela existe" (XAVIER, 2012). Ismael Xavier continua.

\footnotetext{
Nelson Pereira dos Santos faz uma leitura que tinha o jogo temporal em cena como um critério muito importante. Isso torna o filme lento. Este problema é uma coisa que o público reclama no Cinema Novo. Você tem o problema da duração dos planos, do ritmo das caminhadas, que o diretor fez questão de explorar enfaticamente logo de início no filme (XAVIER, 2012).
}

J. C. Ismael não aprecia essa opção estética do Cinema Novo. Para o crítico do jornal O Estado de S. Paulo, "O Sol nos Olhos" (ISMAEL, 1964), este recurso da câmera simboliza a tentativa de dinamizar um espaço e um tempo que deveriam permanecer estáticos. Mas o crítico Claudio Mello e Souza, Jornal do Brasil, argumenta 85 
que a linguagem empregada na obra alude a toda uma realidade do sertão nordestino: "a iluminação crua, a revelação dos grandes espaços, (...) a câmera e a montagem a serviço da revelação do homem - Vidas Secas deu caráter ao cinema brasileiro" (MELLO E SOUZA, 1964).

A maneira como o tempo cinematográfico se relaciona ao texto original está naquilo que Antonio Candido chama de "espírito de jornada", presente nas obras do escritor Graciliano Ramos (CANDIDO, 2012, p. 17). Uma experiência que se desdobra em etapas e que transcorre de forma a terminar em si mesma, de maneira cíclica. Por isso o diretor opta pela duração lenta da dramaticidade cênica, percorrendo a oscilação estrutural entre a fuga e a estabilidade. Ou seja, a questão da sobrevivência da família percorre sem fim toda a narrativa.

\section{Fotografia e sonoridade}

Luiz Carlos Barreto produz o filme ao lado de Nelson Pereira dos Santos e divide a responsabilidade da composição fotográfica com José Rosa. O recurso estilístico é um dos aspectos que chama a atenção no Festival de Cannes. Tom Rowe em O Correio do Povo, "Vidas Secas: sucesso no Festival de Cannes", enfatiza que a imagem do filme é "brutalmente franca e bem fotografada" (ROWE, 1964). Barreto recebe muita atenção na cobertura jornalística, que avalia seu trabalho pelas imagens estouradas, saturadas e agressivas do sertão nordestino. O fotógrafo sintetiza assim a sua participação em Vidas Secas.

Trabalhei na revista O Cruzeiro como repórter e fotógrafo. Fotografei a Copa do Mundo de Futebol de 1958 na Suécia. Nunca havia feito cinema e fui convidado para fazer Vidas Secas. Disse a Nelson Pereira dos Santos que não trabalhava com a luz artificial. E foi assim que deixei o sol invadir a cena, usando isso como linguagem. A fotografia funcionou como a descoberta da luz brasileira e nordestina. Sem a minha experiência de fotógrafo não teria chegado a esta conclusão (BARRETO, 2013).

Em entrevista ao jornal O Estado de S. Paulo, Luiz Carlos Barreto fala sobre o resultado estético de seu trabalho. "Utilizou-se apenas a câmera e o filme, usando lentes sem nenhum filtro, dispensando o rebatedor nos exteriores e o refletor nos interiores, com a consequente valorização dos efeitos naturais de luz e sombra. Somen- te uma cena de exterior noturno, a do 'Reisado', contou com iluminação artificial” (BARRETO, 1964). Vale ressaltar que na visão de alguns críticos, a projeção em tela das matizes do preto-e-branco é recurso para acentuar a faceta documental do filme. O tempo de Fabiano, portanto, se torna nosso, a luz refletida também ilumina e invade o público como espelho da realidade. Percebe-se na pele, olhos e ouvidos um simulacro do castigo que recebe o povo sertanejo.

Nelson Pereira dos Santos dispõe de inúmeras técnicas para evidenciar a família miserável que se movimenta silenciosamente. Além de enfatizar os jogos de oposições campo-cidade, coronel-jagunço e fuga-estabilidade, o diretor também apresenta a dialética homem -animal. Primeiro, com o papagaio de estimação que é estrangulado por Sinhá Vitória quando a família descansa da primeira caminhada pelo semiárido. Segundo, com a cadela Baleia que além de sinalizar situações de perigo, ajuda Fabiano a cercar cabras e caçar o pequeno preá que serve de refeição à família. Baleia é o único ser que traz afeto à família. Mas, ao final, é sacrificada pelo tiro do rifle de Fabiano.

A cachorra Baleia estava para morrer. Tinha emagrecido (...) Então Fabiano resolveu matá-la. Foi buscar a espingarda de pederneira (...) Ela era como uma pessoa da família (...) Coitadinha da Baleia (...) Inconveniência deixar cachorro doido solto em casa (RAMOS, 2012, p. $85)$.

A reação do público francês em relação ao sacrifício da cachorrinha em cena é um dos acontecimentos inesperados do festival. É o que relata Luís Edgar de Andrade ao Jornal do Brasil, "Cannes quis Salvar Baleia para Alegrar Vidas Secas, mas Produtor não Permitiu” (ANDRADE, 1964). Luiz Carlos Barreto mantem este plano-sequência ao conjunto do filme. Para acalmar os ânimos dos recém-conquistados fãs da célebre cadelinha, a reportagem "Artes na Semana" evidencia que a comitiva brasileira se mostra atenciosa com os franceses. "Por iniciativa da Air France, a cachorrinha Baleia foi transportada a Cannes para mostrar que está viva e anular o protesto da Sociedade Francesa de Proteção aos Animais" (O ESTADO DE S. PAULO, 1964). Detalhe curioso na Folha de S. Paulo (10/06/1963) é verificar nota que revela o valor pago ao dono da cachorra Piaba, intérprete de Baleia. 
Vale ressaltar que diferentemente de Baleia os meninos não possuem nome. A pesquisadora Darlene Sadlier descreve detalhes da função simbólica de Baleia no filme.

Apesar de nunca escutarmos os pensamentos de Baleia (como fazemos no romance), ela é de fato a única personagem no filme cujo "discurso" é representado de modo consistente, na forma de uma sincronia entre ação e som; seus latidos são reconhecidos e recebem a atenção da família como se fossem palavras (SADLIER, 2012, p. 51).

$\mathrm{Na}$ trilha sonora, a ação do ruído dos instrumentos de corda integra todo o roteiro, relacionandose ao som ardente de rodas vagarosas e emperradas. $\mathrm{Ou}$ seja, a metáfora da lenta dor da família nômade e errante em natureza hostil. Vidas Secas é manifesto contra a pobreza opressiva, fruto das contradições entre o poder constituído (estado) e a cidadania (nação).

Algo que poucos críticos percebem - ou ao menos não comentam - é que Vidas Secas é produção híbrida. É esta característica que reside a sua maior originalidade. Ou seja, é obra heterogênea que transita entre a concepção cinemanovista - movimentação da câmera, dramaturgia, fotografia - e o uso do ponto de vista, em momentos pontuais, que Nelson Pereira dos Santos utiliza do cinema comercial. Ismail Xavier explica a cena do menino mais velho ao pensar deitado sobre o chão de terra.

Quando Nelson constrói um capítulo do livro em que você tem a visão do menino maior, ele estabelece visualmente este ponto de vista. A montagem cria isto, justamente com o jogo de campo e de contra-campo (...) ele foi muito inteligente ao gerar esta leitura, que eu chamo de 'sair do aspecto regionalista' (XAVIER, 2012).

\section{Entre o rural e o urbano}

Carlos Heitor Cony da Folha de S. Paulo é um dos jornalistas que se manifesta pela ausência dos espaços urbanos na produção cinematográfica. "Vi apenas os vinte minutos iniciais de Vidas Secas. Homem de cida- de, pequeno-burguês por nascimento, formação e hábito, basta a silhueta de uma vaca para me dar arrepios e tédio" (CONY, 1964). Vale salientar que durante o governo militar, a representação do urbano é indesejável e embaraçosa.

A ação militar - mobilizada pelo custo de vida alto e inflação no final dos anos do governo Juscelino Kubitschek (1956-1961) - promove a expansão do capitalismo. O modelo de 1964 conta com as forças do Brasil rural, como o coronelismo latifundiário. E com as forças do Brasil urbano, como a elite empresarial aliada ao investimento estrangeiro e contrária ao crescimento do comunismo. Pela acentuada deterioração da qualidade da vida urbana (educação, saúde, transportes, salários), o regime militar exerce repressão a todo tipo de liderança ou organização (intelectual, política, artística, estudantil, trabalhadora), "num disfarce ideológico requintado que apresentava o país mergulhado num reino de virtudes" (FERREIRA de OLIVEIRA, 1987, p. 24).

Fabiano assume um papel desbravador pelo realismo do personagem rural na tela, se comparado a outros protagonistas do cinema, como Firmino e Aruã em Barravento (Glauber Rocha, 1962), que são heróis românticos e mártires populares inexistentes. Em Fabiano não há tais pretensões. Ele é o retrato do brasileiro: humano e contraditório. Inspirado em Seu Tomás que sabe ler, busca a consciência de si mesmo, que faz dele um lutador e uma vítima, sinalizando o êxodo rural. "Embora não tenham condições de ser gente, sabem que não são gente e aspiram a sê-lo" (BERNADET, 2007, p. 82).

Graciliano Ramos finaliza o seu romance, sugerindo à família um salto civilizatório do rural ao urbano e do nordeste ao sudeste. O sertão, portanto, deveria ser abandonado. A aspiração de Fabiano e Sinhá Vitória gira em torno da premissa social: ir à cidade grande e alçar "voo" longe da seca e do latifúndio.

Iriam para diante, alcançariam uma terra desconhecida. Fabiano estava contente e acreditava nessa terra, porque não sabia como ela era nem onde era (...) $\mathrm{E}$ andavam para o sul, metidos naquele sonho. Uma cidade grande, cheia de pessoas fortes. Os meninos em escolas, aprendendo coisas difíceis e necessárias (...) Chegariam a uma terra desconhecida e civilizada, ficariam presos nela. E o sertão continuaria a mandar gente para lá. O sertão mandaria para a cidade ho- 
mens fortes, brutos, como Fabiano, sinhá Vitória e os dois meninos (RAMOS, 2012, p. 127).

Jean-Claude Bernardet minimiza a objetividade com que o filme evidencia a crise social nordestina, para ressaltar outras funções que a película exerce. "O filme foi qualificado como naturalista (...) quase um documentário, quando ele representa o mais alto grau de abstração atingido entre nós pelo cinema" (BERNADET, 2007, p. 87). O crítico identifica na história sertaneja uma das primeiras caracterizações apuradas da vida urbana e do "pequeno-burguês citadino". Essa extravagância interpretativa só é possível graças a Nelson Pereira dos Santos, que transcreve para a tela não só a universalidade presente no romance de Graciliano Ramos, mas a sua versão atualizada para a época, que se apresenta bem mais urbanizada do que o texto literário.

Comparando o audiovisual ao romance, Bernardet menciona a própria organização da família sertaneja que, mesmo sendo a estipulada por Graciliano no romance, é identificada com a estrutura convencional da família burguesa urbana. E essa relação se torna plausível na construção cinematográfica pela origem paulistana de Nelson Pereira dos Santos: "Para chegar a esse resultado era necessário que o autor fosse um homem da cidade" (BERNADET, 2007, p. 82). O crítico aponta o poder de síntese do diretor e a maneira com que as possibilidades de reação e de confronto são postas. "Vidas Secas é um filme urbano a respeito do campo" (BERNADET, 2007, p. 82).

\section{Sem políticas públicas}

Inspirados em Seu Tomás, Sinhá Vitória quer ter uma confortável cama, já Fabiano pretende falar bem a língua portuguesa. Entretanto, o casal sabe o que deseja em seus monólogos de discurso indireto: migrar para a cidade e educar os filhos. Ou seja, sair deste estado de ignorância e torpor, tal desejo revela o lugar aprisionante da gente brasileira.

"Em cinema, o subdesenvolvimento não é uma etapa, um estágio, mas um estado" (SALLES GOMES, 1980 , p. 85). Nos anos 1960, o cinema brasileiro não chega a ser uma indústria e consequentemente não tem uma produção cadenciada e variada de conteúdo. Isso por dois fatores. Primeiro, as tentativas de desenvolvimento enfrentam a desleal concorrência do cinema estrangeiro - mais especificamente do cinema norte-americano. Segundo, o brasileiro absorve facilmente a qualidade técnica, os estereótipos e os valores regentes do cinema hollywoodiano. "Somos um prolongamento do ocidente (...) não há a carapaça cultural exótica que protegeu certa originalidade na produção de filmes na Arábia Saudita e na Índia” (SALLES GOMES, 1980, p. 89).

O filme de Nelson Pereira dos Santos é forma de contestação em relação à política brasileira. No período de mais de duas décadas de ditadura militar, Vidas Secas se une a grupos de oposição ao regime autoritário dos quais fazem parte artistas, músicos, jornalistas, intelectuais, que expressam suas aspirações e indignações. A imprensa cobre Vidas Secas com detalhes e predominância de elogios, embora não seja possível detectar, neste período ditatorial de perda das liberdades democráticas, os artigos censurados dos meios de comunicação.

Considerado um dos primeiros do gênero cinema de autor, o filme não se configura como norma para atestar a cinematografia nacional. Mas, mesmo sendo um caso particular, gera extensa repercussão na crítica jornalística e literária. Vidas Secas é o único filme brasileiro a ser indicado pelo British Film Institute como uma das 360 obras fundamentais dentro de uma cinemateca.

A história de Fabiano e sua família, arte literária e cinematográfica estimulante para pensar o país, é marco na caracterização de nosso povo. $\mathrm{O}$ audiovisual brasileiro ainda hoje percorre enredo análogo ao proposto por Graciliano Ramos. Isto é, desenvolve jornadas cíclicas nessa realidade de terra seca e desconhecida em que o espelho cultural sobrevive nebuloso. Apesar do aumento da produção proporcionada pela indústria de entretenimento e pelos meios digitais, constata-se que a natureza estética e poética que se vê em Vidas Secas é ainda iniciativa heroica e isolada na construção da identidade brasileira. E que compõe um dos polípticos deste raro encontro.

\section{Referências}

AVANCINI, Atílio. Atílio Avancini. Série artistas da USP n.15. São Paulo: Edusp, 2006.

Entre Gueixas e Samurais: fotografias e relatos de viagem. São Paulo: Edusp - Imprensa Oficial, 2008.

A Imagem Fotográfica do Cotidiano: significado e informação no jornalismo. In: Brazilian Journalism Research, vol. 7, n. 1, p. 50-68, 2011.

AZEREDO, Ely. Olhar Crítico - 50 anos de cinema brasileiro. Rio de Janeiro, Instituto Moreira Salles, 2009. 
BERNARDET, Jean-Claude. Brasil em Tempo de Cinema. São Paulo, Companhia das Letras, 2007.

Cinema Brasileiro: propostas para uma história. São

Paulo, Companhia das Letras, 2009.

CANDIDO, Antonio. Ficção e confissão: ensaio sobre a obra de Graciliano Ramos. Rio de Janeiro, Ed. Ouro Sobre Azul, 2012.

Os Bichos do Subterrâneo. In: CANDIDO, Antonio. Fiç̧ão e confissão: ensaio sobre a obra de Graciliano Ramos. Rio de Janeiro, Ed. Ouro Sobre Azul, 2012.

—. Tese e Antítese: ensaios. São Paulo, Ed. Nacional, 1978.

CARPEAUX, Otto Maria. Visão de Graciliano Ramos. In: _. Origens e Fins. Rio de Janeiro, Ed. Casa do Estudante do Brasil, 1943.

FERREIRA de OLIVEIRA, Sérgio Murilo. Os Trabalhadores Urbanos e a Ditadura Militar. In: Revista $A d$ ministração Pública, Rio de Janeiro, p. 24-36, abril-junho 1987.

HOLANDA, Sérgio Buarque de. O Espirito e a Letra. In: ARNONI PRADO, Antonio (org). São Paulo, Companhia das Letras, 1996.

JOHNSON, Randal. Vidas Secas and the Politics of Filmic Adaptation. In: Ideologies and Literature III, $\mathrm{n}^{\circ}$ 15, janeiro-março/1981.

RAMOS, Graciliano. Vidas Secas. São Paulo, Record, 2012.

SADLIER, Darlene. Nelson Pereira dos Santos. Campinas, Papirus, 2012.

SALLES GOMES, Paulo Emílio. Cinema: trajetória no subdesenvolvimento. Rio de Janeiro, Ed. Paz e Terra, 1980.

STAM, Robert, JOHNSON, Randal. The Cinema of Hunger: Nelson Pereira dos Santos's Vidas Secas. In: JOHNSON, Randal; STAM, Robert. Brazilian Cinema. London, Associated University Presses, 1982.

Ad. Folha de S. Paulo. São Paulo, 17 agosto 1963.

Ad. Vidas Secas. Correio da Manhã. Rio de Janeiro, 31 agosto 1963.
Ad. Vidas Secas é a Grande Atração. O Estado de S. Paulo. São Paulo, 03 março 1964, p. 14.

Ad. Fitas para o Festival de Cannes. O Estado de S. Paulo. São Paulo, 01 abril 1964.

Ad. Vidas Secas, $1^{a}$ da América em Cannes. Folha de $S$. Paulo. São Paulo, 30 abril 1964.

Ad. Artes na Semana. O Estado de S. Paulo. São Paulo, 10 maio 1964.

Ad. O Estado de S. Paulo. São Paulo, 26 setembro 1964.

ANDRADE, Luís Edgar. Cannes Quis Salvar Baleia para Alegrar Vidas Secas, Mas Produtor não Permitiu. Jornal do Brasil. Rio de Janeiro, 30 abril 1964.

BARRETO, Luiz Carlos. O Estado de S. Paulo. São Paulo, 26 setembro 1964.

CONY, Carlos Heitor. Vidas Secas. Folha de S. Paulo. São Paulo, 26 junho 1964.

ISMAEL, J. C. O Sol nos olhos. O Estado de S. Paulo (Suplemento Literário). São Paulo, 23 maio 1964.

MELLO E SOUZA, Claudio. Jornal do Brasil. Rio de Janeiro, 21 abril 1964.

MAIA, Oliveira. Itamarati Selecionou Filme para o Festival de Cannes. O Jornal. Rio de Janeiro, 14 março 1964.

NEVES, David E. A Verdade do Nordeste. O Estado de S. Paulo (Suplemento Cultural). São Paulo, 21 dezembro 1963.

ROWE, Tom. Vidas Secas: Sucesso no Festival de Cannes. O Correio do Povo. Florianópolis, 03 maio 1964.

SALLES GOMES, Paulo Emílio. Vidas Secas Respeitou Espírito de Graciliano. Visão. São Paulo, 13 dezembro 1963 , p. 70.

SAMPAIO, Silveira. Um Filme para Kennedy Ver. Diário de Notícias. Rio de Janeiro, 30 agosto 1963.

TEIXEIRA, Novaes. França Vence em Cannes: 3 Prêmios para Fita Brasileira. O Estado de S. Paulo. São Paulo, 15 maio 1964.

89 
- Palavras do Diretor. O Estado de S. Paulo. São

Paulo, 15 maio 1964.

\section{Entrevistas}

BARRETO, Luiz Carlos. Sportv (Sportv Repórter). Rio de Janeiro, 30 setembro 2013.

CANDIDO, Antonio. Depoimento para os autores em São Paulo, 16 junho 2012.

XAVIER, Ismail Norberto. Depoimento para os autores em São Paulo, 17 maio 2012.

\section{Filmografia}

Barravento. Direção: Glauber Rocha (1962).

Deus e o Diabo na Terra do Sol. Direção: Glauber Rocha (1963).

Les Parapluies de Cherbourg. Direção Jacques Demy (1964).

O Pagador de Promessas. Direção Anselmo Duarte (1962).

Vidas Secas. Direção: Nelson Pereira dos Santos (1963). Produção: Nelson Pereira dos Santos, Luiz Carlos Barreto. Elenco: Átila Iório, Maria Ribeiro, Gilvan Lima, Genivaldo Lima, Joffre Soares, Orlando Macedo. Roteiro: Nelson Pereira dos Santos. Fotografia: Luiz Carlos Barreto, José Rosa. Trilha Sonora: Leonardo Alencar. Sino Filmes, 103 minutos, VHS, sonoro, preto-e-branco. 